\title{
A REVIEW OF THE MEDICINAL FERNS OF UKRAINE
}

\section{Valentyna Minarchenko ${ }^{1}$, Iryna Tymchenko ${ }^{2}$, Tetyana Dvirna ${ }^{2}$, Larysa Makhynia ${ }^{1}$}

\author{
${ }^{1}$ Department of Pharmacognosy and Botany, \\ Bohomolets National Medical University, Kiyv, Ukraine \\ ${ }^{2}$ Department of Systematics and Floristics of Vascular Plants, \\ M.G. Kholodny Institute of Botany, National Academy of Sciences of Ukraine
}

\begin{abstract}
The growing demand for natural medicines, food products and cosmetics stimulates the search and studies on the diversity of plant species. Ferns are a promising source of biologically active substances for pharmaceutical and medical purposes. Out of 63 species of wild ferns in Ukraine, 39 species contain biologically active substances, which are used or can be used for medicinal and food purposes. Most of them have limited distribution and resources. Many of them are endangered and are in need of protection. This article highlights some aspects of the distribution, resource significance, and protection status in Ukraine and/or Europe, as well as the medicinal value of the wild medicinal ferns of Ukraine.
\end{abstract}

Keywords: wild medicinal ferns, resources significance, protection

\section{INTRODUCTION}

Nowadays, the investigation of the available diversity and resources of medicinal plants has become an important subject and is progressing in the spheres of biodiversity and conservation. Ferns are an important component of phytodiversity and have value as medicinal, ornamental, edible and technical plants in different regions of the world.

Ferns are thought by most people to have low value for medical purposes. In the traditional medicine of Ukraine and that of most of the European countries, their useful aspects are largely limited. Ferns are popular plants as food, medicine, decora-

Address for correspondence:

Valentyna Minarchenko

Department of Pharmacognosy and Botany

Bohomolets National Medical University

13 Tarasa Shevchenko Blvd

01601 Kiyv

Ukraine

e-mail:valminar@ukr.net

Received: May 2, 2017

Accepted: June 27, 2017 tion, fiber, crafts and building material mostly in the countries of Southeast Asia (1-6).

Nowadays, the medicinal properties of ferns in regard to human health are being more thoroughly studied. According to various data, ferns contain many secondary metabolites, as well as polyphenols, flavonoids, triterpenoids, etc. $(7,8)$. Ferns have various functional effects on human health, such as antioxidant, antimicrobial, antitumor, anti-inflammatory and more, which are classified as the effects of secondary metabolites $(9,10)$. It has been confirmed that antioxidant activity of the secondary metabolites of ferns is the most useful bioactivity for countering aging and chronic disease (1).

Therefore, this study was conducted in order to create a database of wild medicinal ferns of Ukraine, their resource significance, protection status in Ukraine or Europe and medicinal value, based on a long-term research, results of literature data analysis and local ethnobotanical knowledge. There are nearly 63 wild species, subspecies and hybrids of fern in Ukraine (11). In this study, a total of 39 wild species of ferns native to Ukraine, which are considered medicinal in the world, were analyzed. This research 


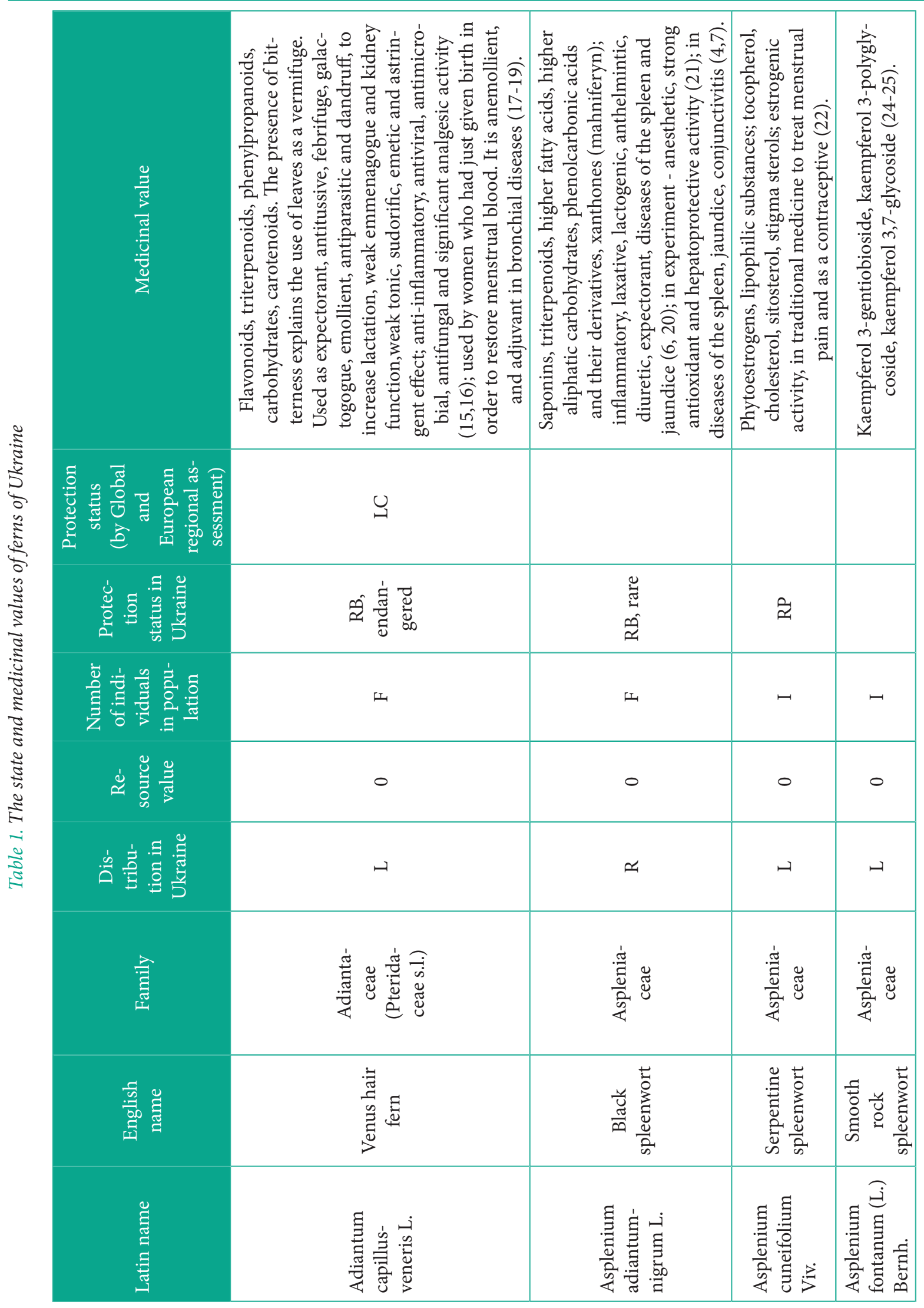


Valentyna Minarchenko, Iryna Tymchenko, Tetyana Dvirna et al.

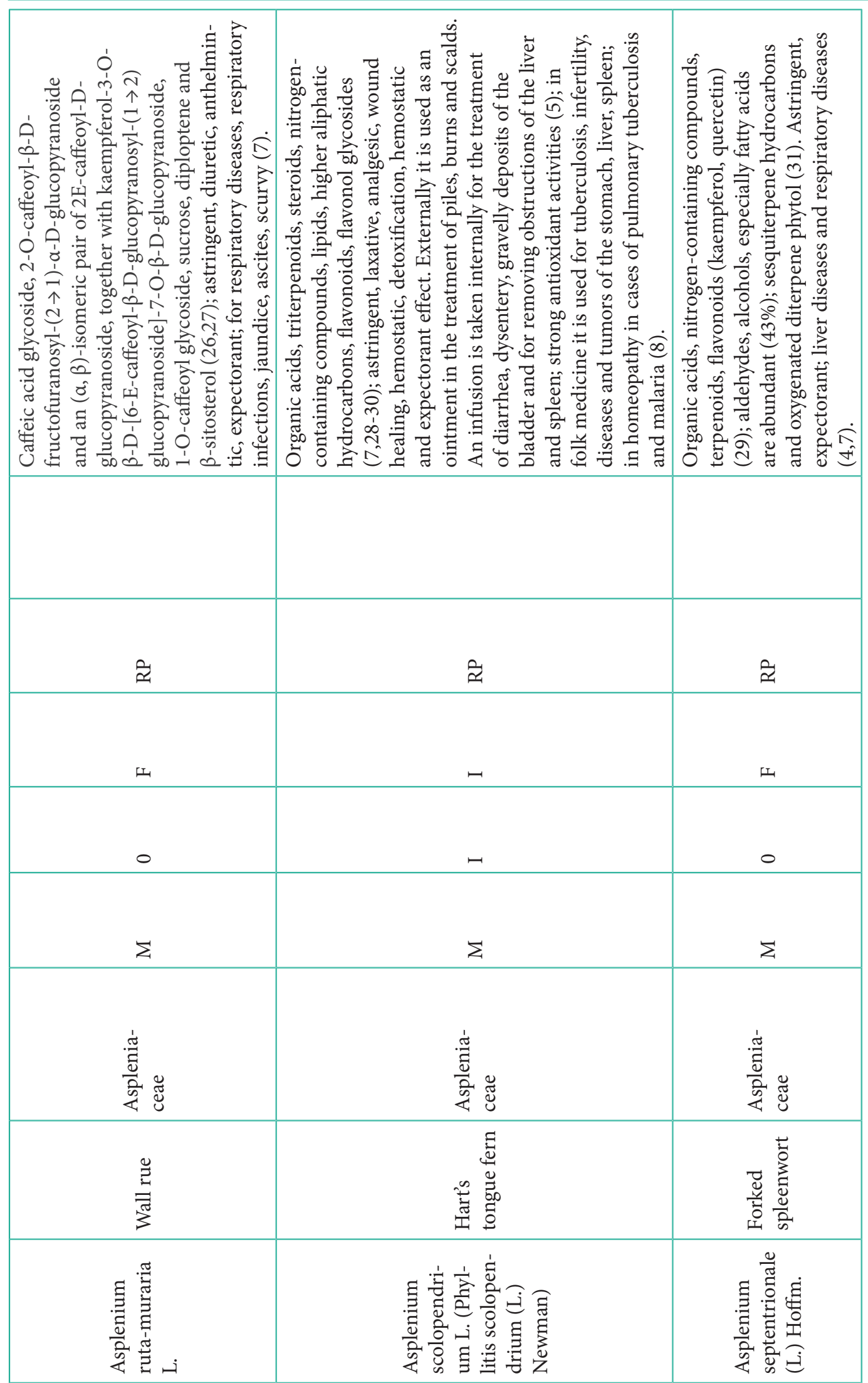

Scripta Scientifica Pharmaceutica, vol. 4, No. 1, 2017, pp. 7-23 Medical University of Varna 
A Review of the Medicinal Ferns of Ukraine

\begin{tabular}{|c|c|c|c|c|}
\hline 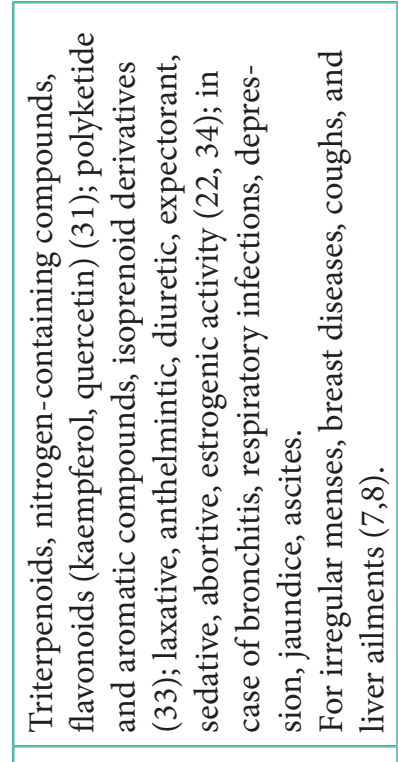 & 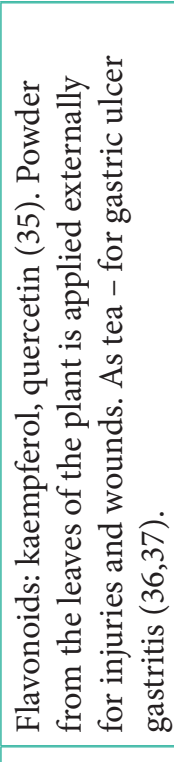 & 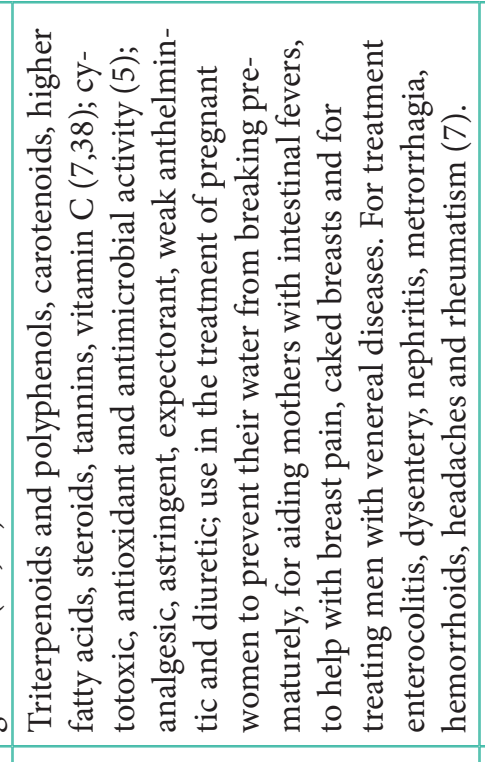 & 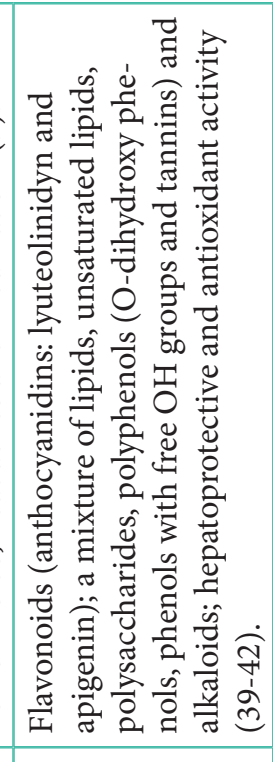 & 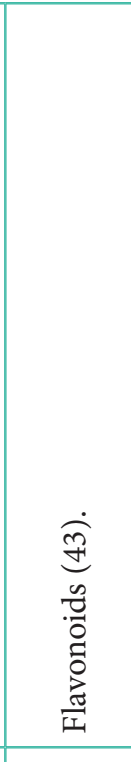 \\
\hline$\ddot{\approx}$ & $\ddot{\approx}$ & $\ddot{\approx}$ & & \\
\hline 山 & $r$ & z & $z$ & 山 \\
\hline 0 & 0 & $\Xi$ & 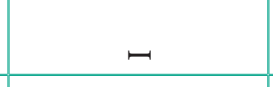 & 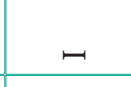 \\
\hline$\Sigma$ & $\simeq$ & $\Sigma$ & $\simeq$ & $\approx$ \\
\hline 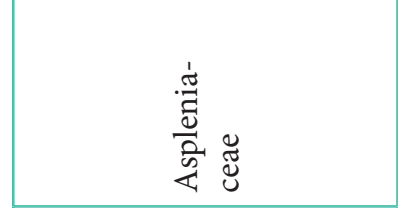 & 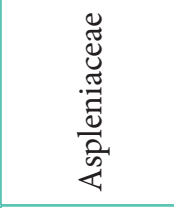 & 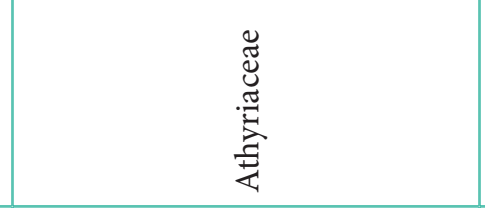 & 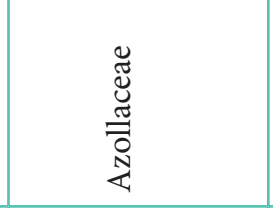 & 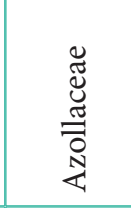 \\
\hline 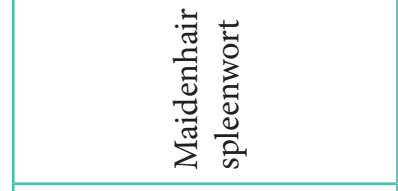 & 范 & 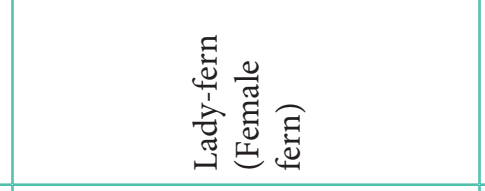 & 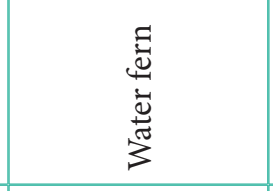 & 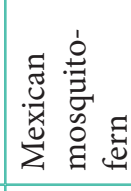 \\
\hline 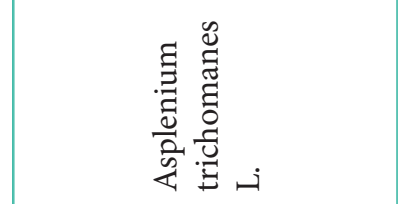 & 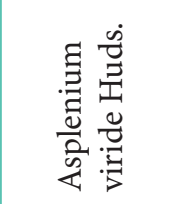 & 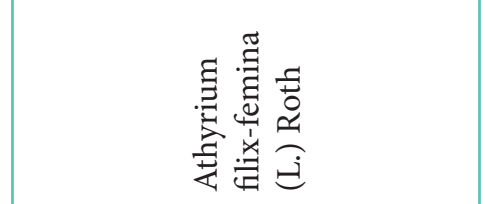 & 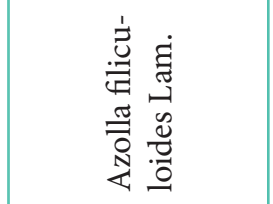 & 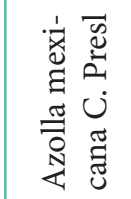 \\
\hline
\end{tabular}


Valentyna Minarchenko, Iryna Tymchenko, Tetyana Dvirna et al.

\begin{tabular}{|c|c|c|c|c|c|}
\hline 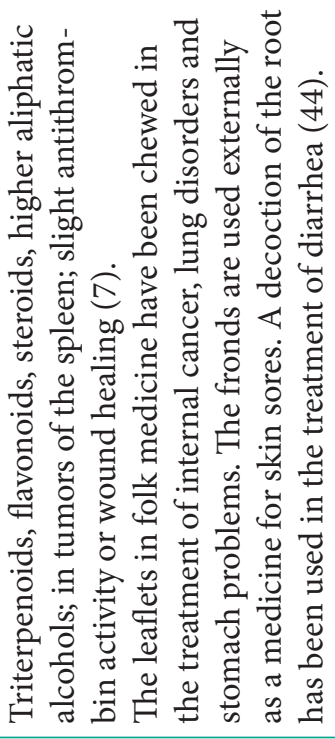 & 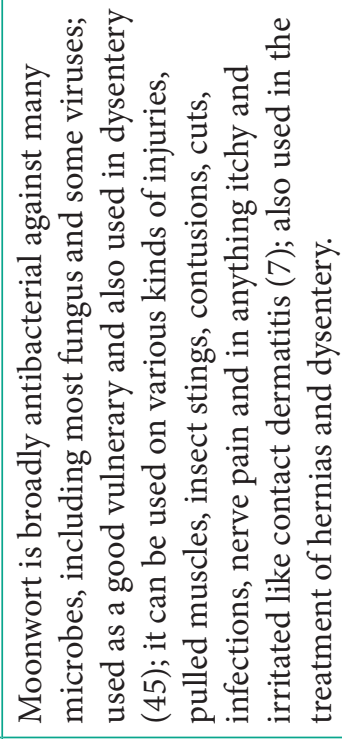 & 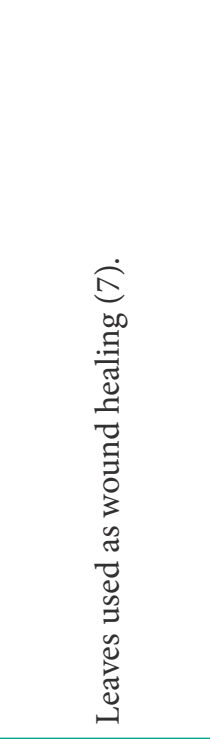 & 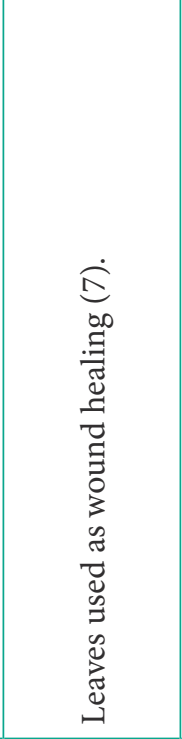 & 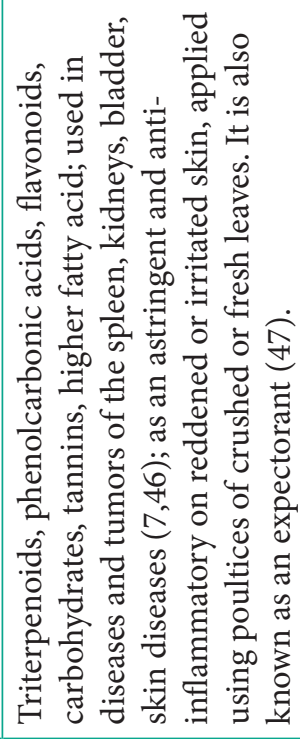 & 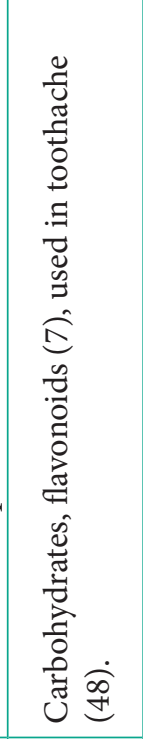 \\
\hline & U & 枀 & $\hat{\mathrm{\theta}}$ & & \\
\hline حิ & 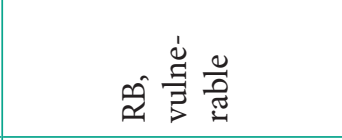 & 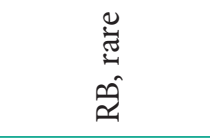 & 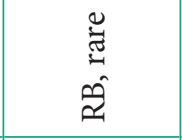 & & 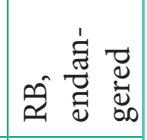 \\
\hline 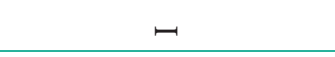 & - & - & 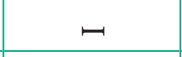 & - & $\neg$ \\
\hline 0 & 0 & 0 & 0 & 0 & 0 \\
\hline$\simeq$ & $\simeq$ & $\simeq$ & $\simeq$ & ـ & ــ \\
\hline 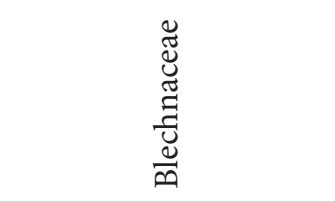 & 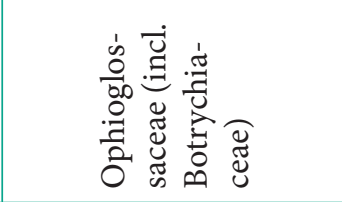 & 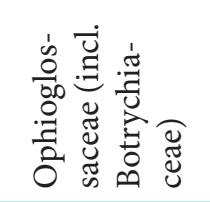 & 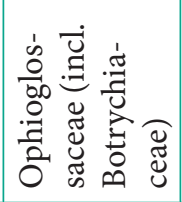 & 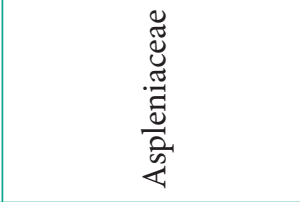 & \\
\hline 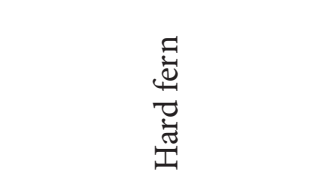 & 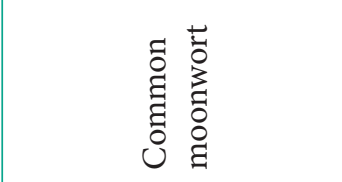 & 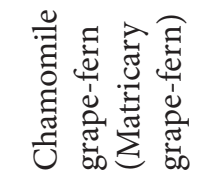 & 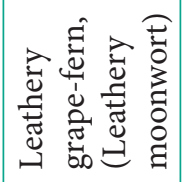 & 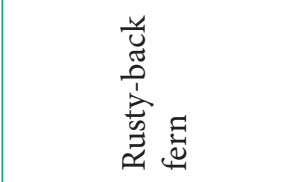 & 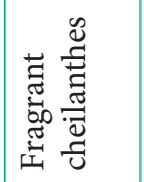 \\
\hline 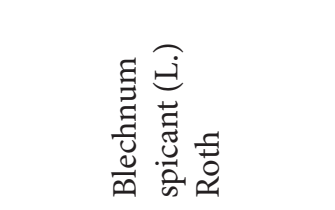 & 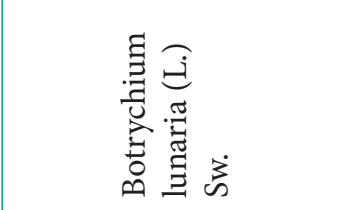 & 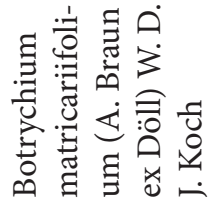 & 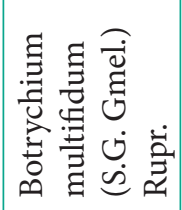 & 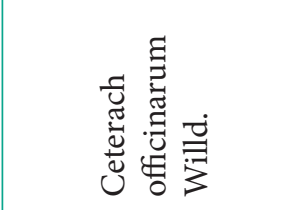 & 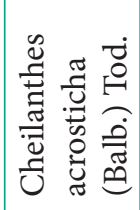 \\
\hline
\end{tabular}

Scripta Scientifica Pharmaceutica, vol. 4, No. 1, 2017, pp. 7-23 
A Review of the Medicinal Ferns of Ukraine

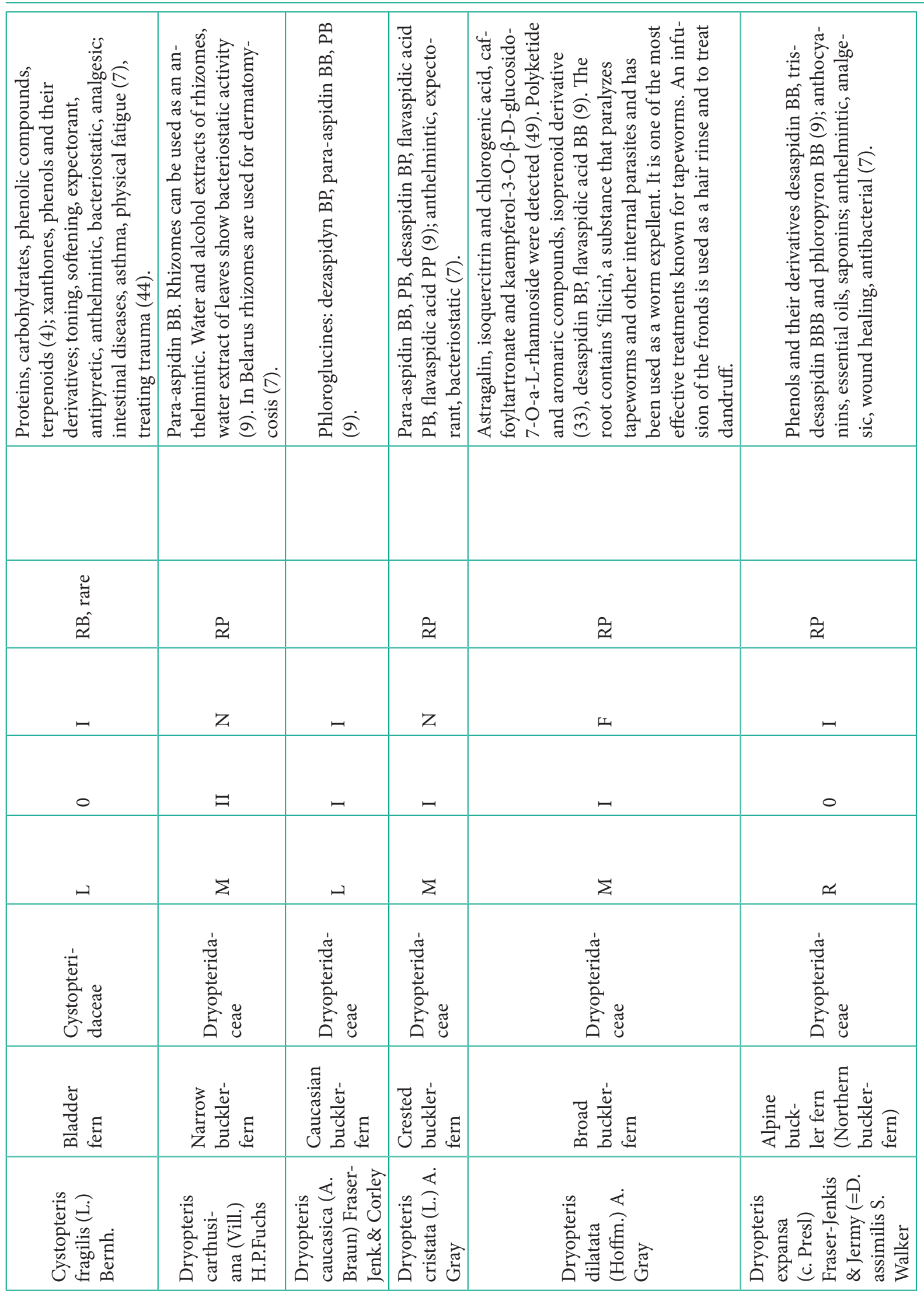


Valentyna Minarchenko, Iryna Tymchenko, Tetyana Dvirna et al.

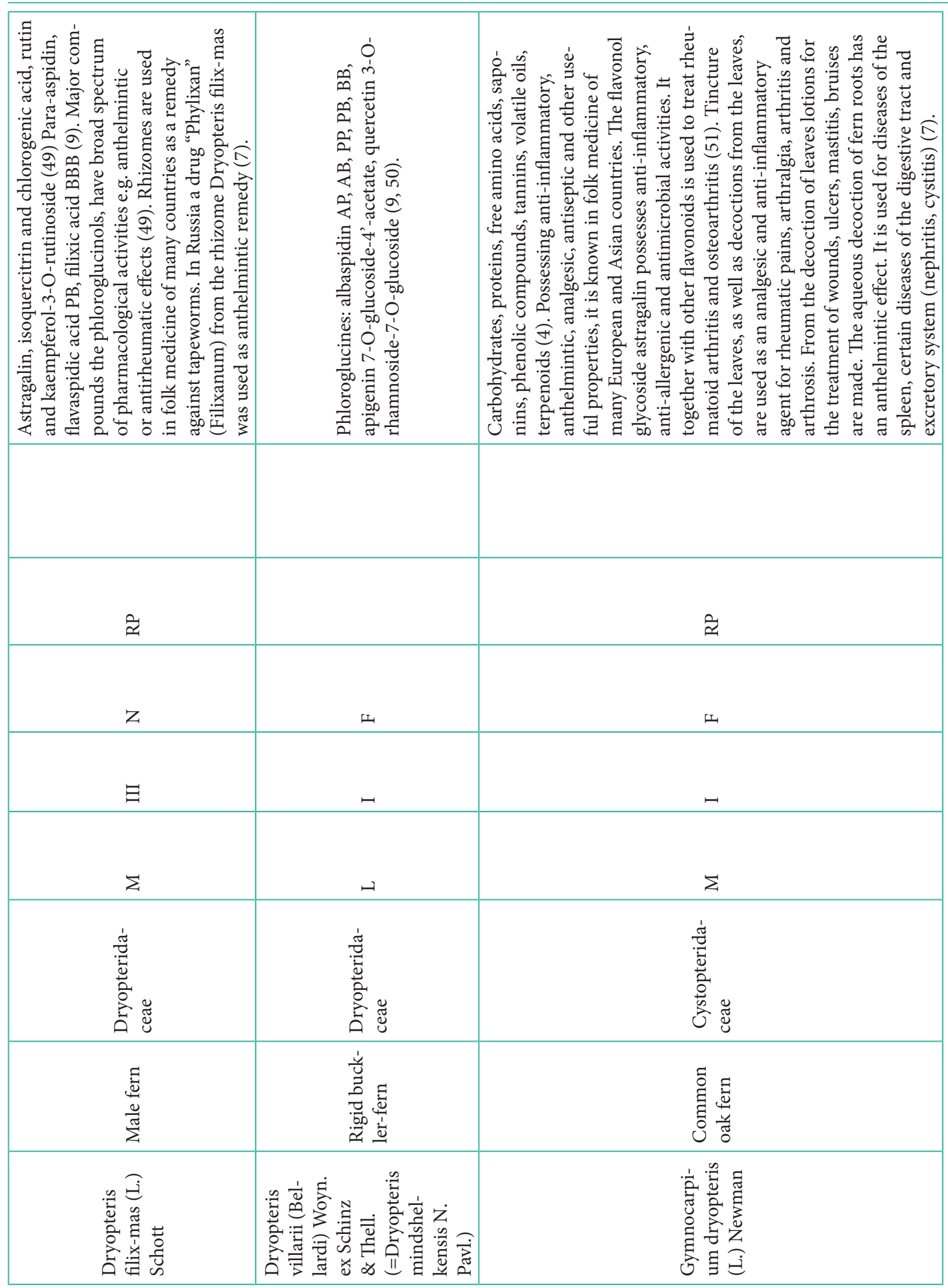

Scripta Scientifica Pharmaceutica, vol. 4, No. 1, 2017, pp. 7-23 
A Review of the Medicinal Ferns of Ukraine

\begin{tabular}{|c|c|c|c|c|}
\hline 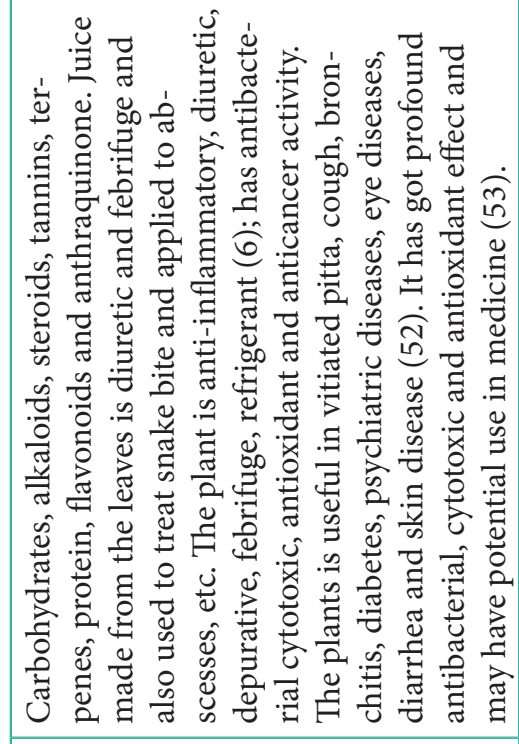 & 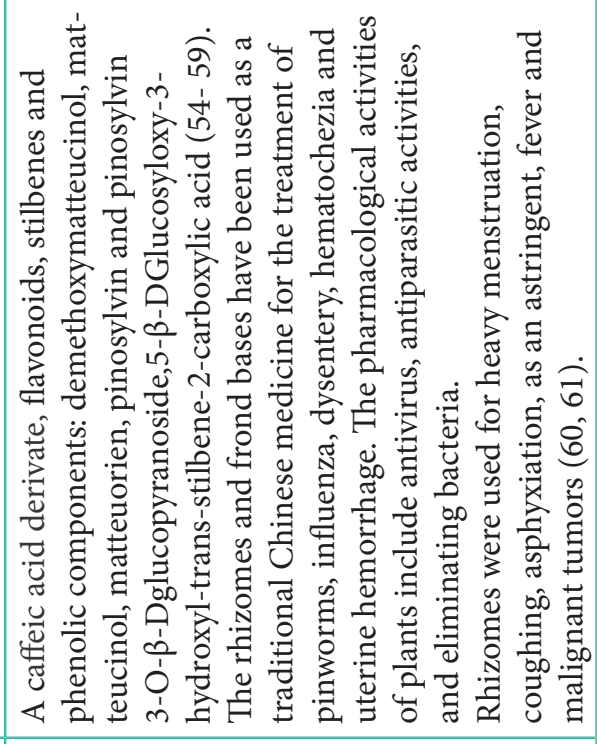 & 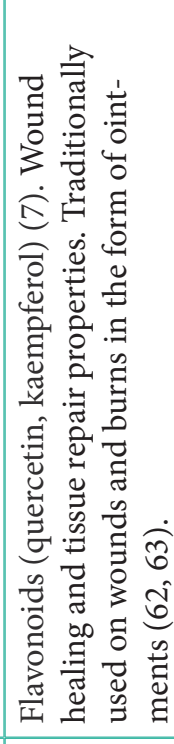 & 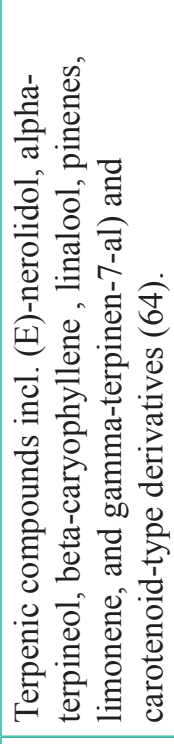 & 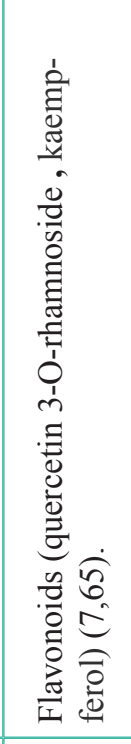 \\
\hline 公 & $\mathcal{U}$ & & & 乬 \\
\hline 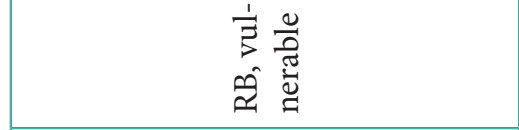 & ฉิ & ฉิ & $\ddot{\approx}$ & 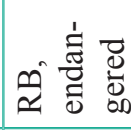 \\
\hline- & w & 山 & - & - \\
\hline 0 & 0 & $r$ & 0 & 0 \\
\hline$\simeq$ & $\Sigma$ & $\Sigma$ & ــ & - \\
\hline 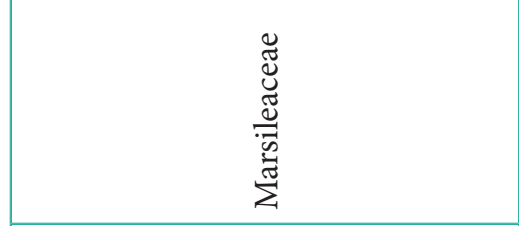 & 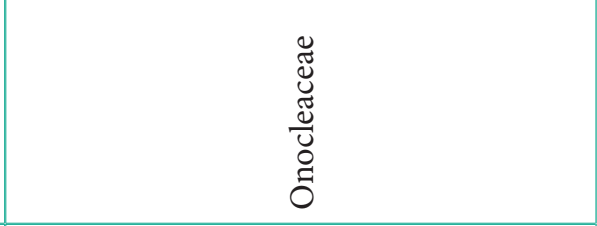 & 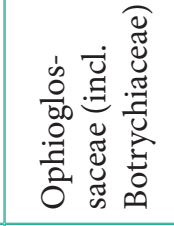 & 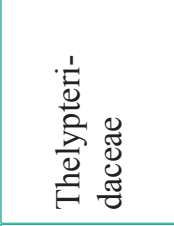 & 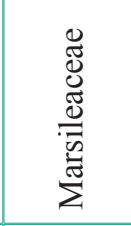 \\
\hline 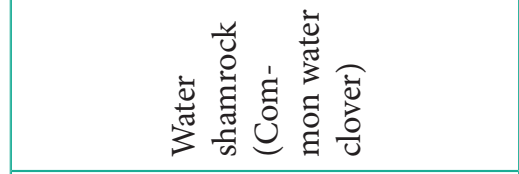 & 苞 & 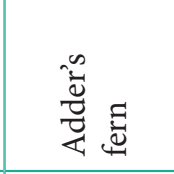 & 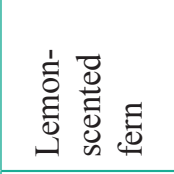 & 颜 \\
\hline 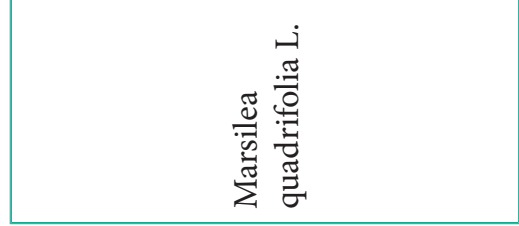 & 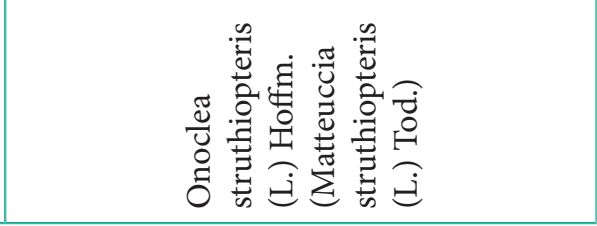 & 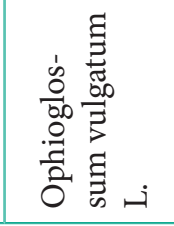 & 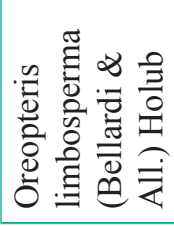 & 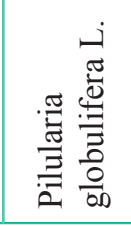 \\
\hline
\end{tabular}


Valentyna Minarchenko, Iryna Tymchenko, Tetyana Dvirna et al.

\begin{tabular}{|c|c|c|}
\hline 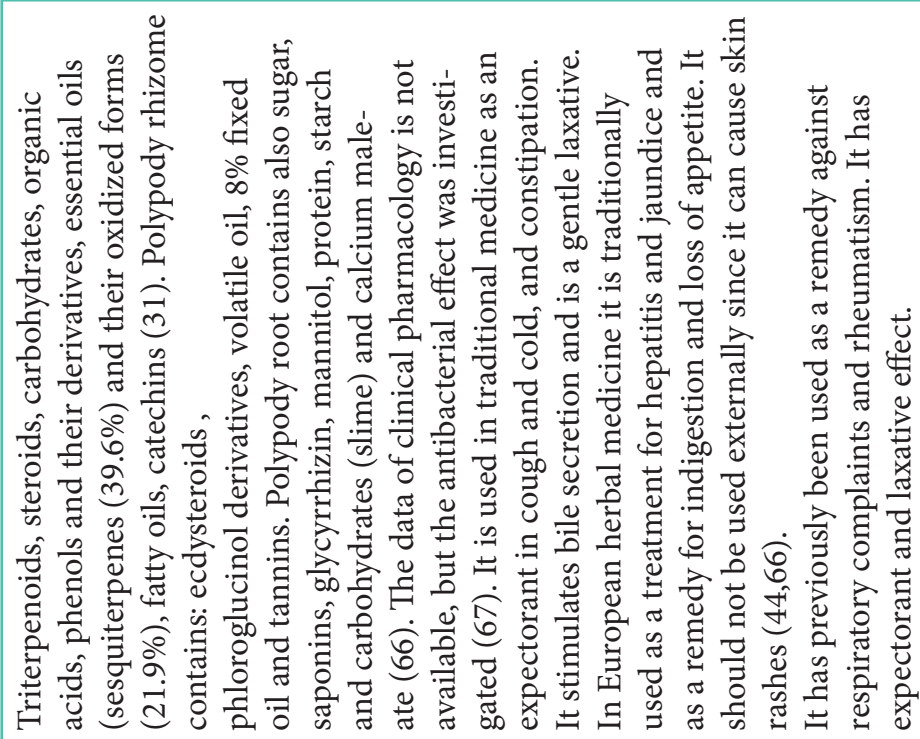 & 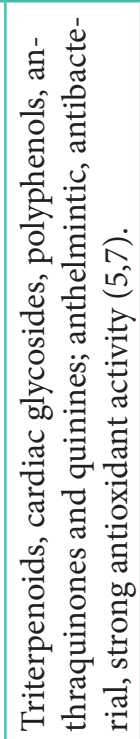 & 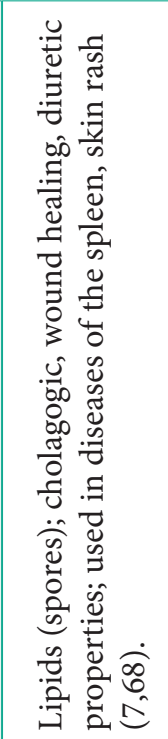 \\
\hline \multicolumn{3}{|l|}{$\stackrel{\cup}{\cup}$} \\
\hline حِ & حิ) & حِ \\
\hline$\omega$ & - & - \\
\hline - & $\varpi$ & 0 \\
\hline$\Sigma$ & $\simeq$ & $\simeq$ \\
\hline 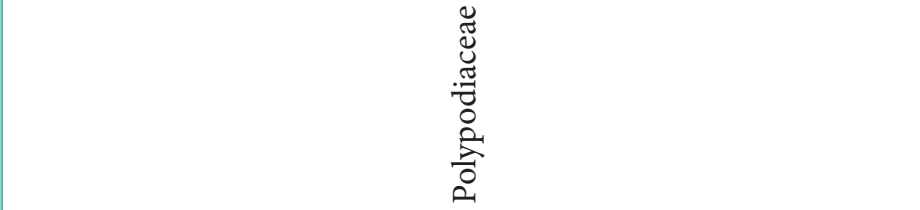 & 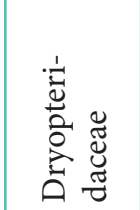 & 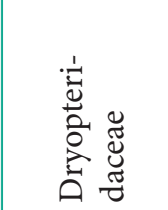 \\
\hline 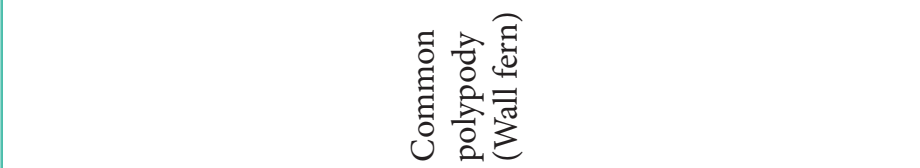 & 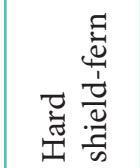 & 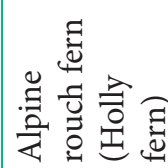 \\
\hline 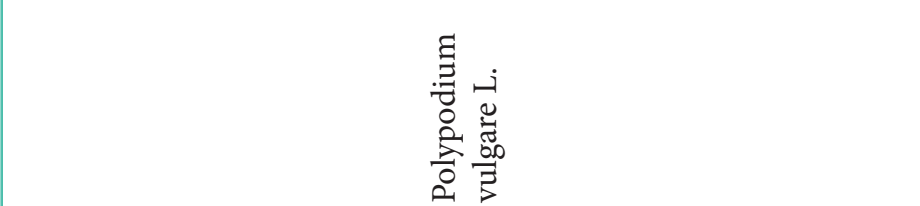 & 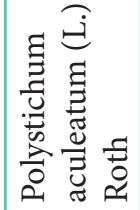 & 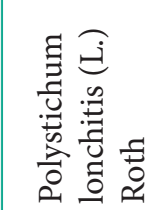 \\
\hline
\end{tabular}

Scripta Scientifica Pharmaceutica, vol. 4, No. 1, 2017, pp. 7-23 
A Review of the Medicinal Ferns of Ukraine

\begin{tabular}{|c|c|}
\hline 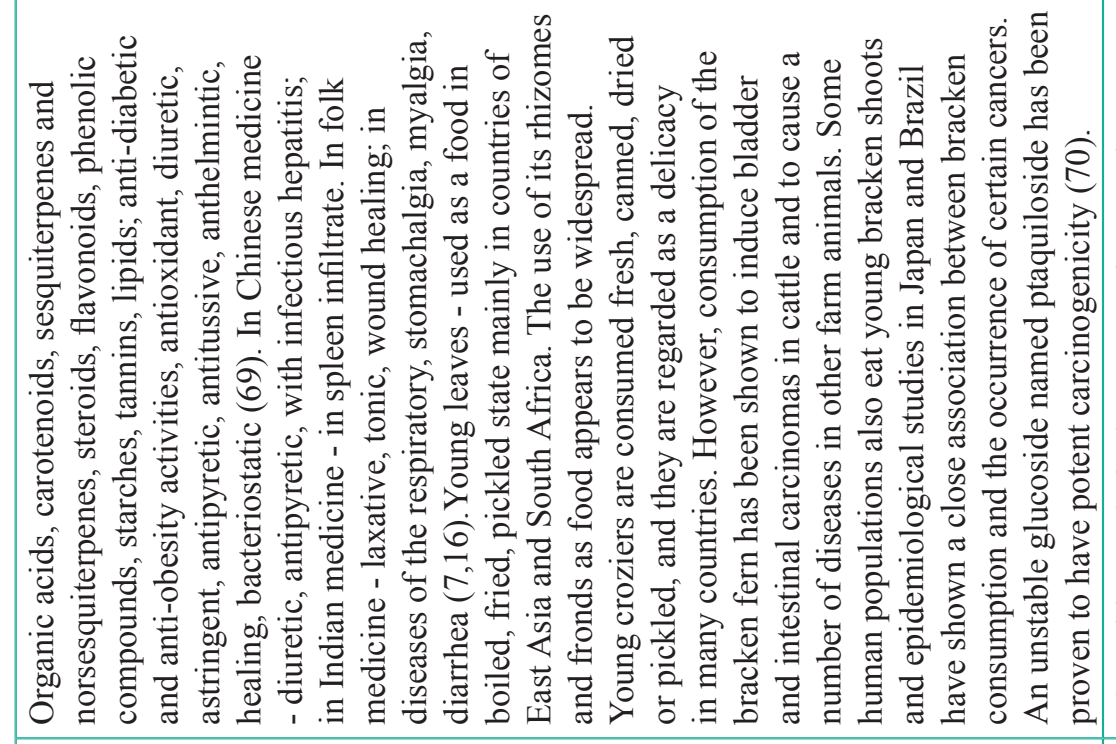 & 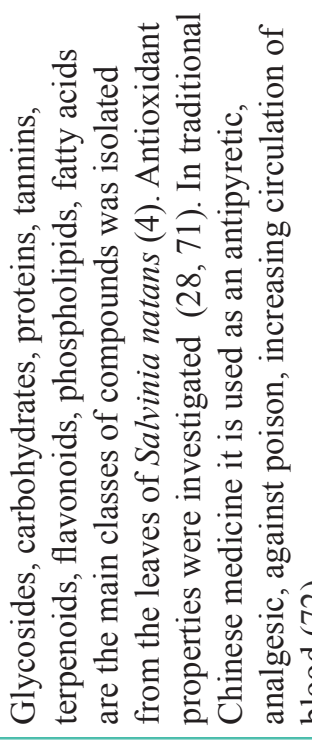 \\
\hline & U \\
\hline & 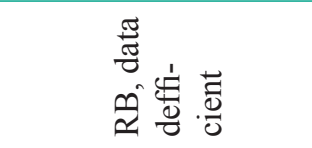 \\
\hline z & $z$ \\
\hline$\Xi$ & 0 \\
\hline$\Sigma$ & $\Sigma$ \\
\hline 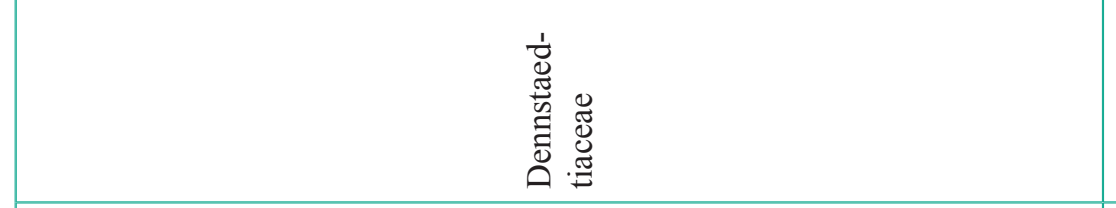 & 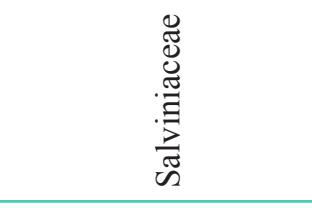 \\
\hline 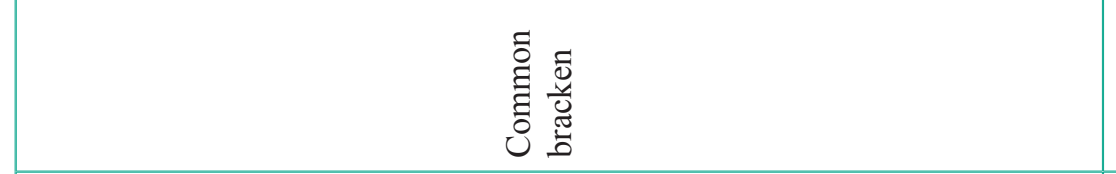 & 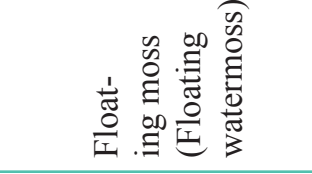 \\
\hline 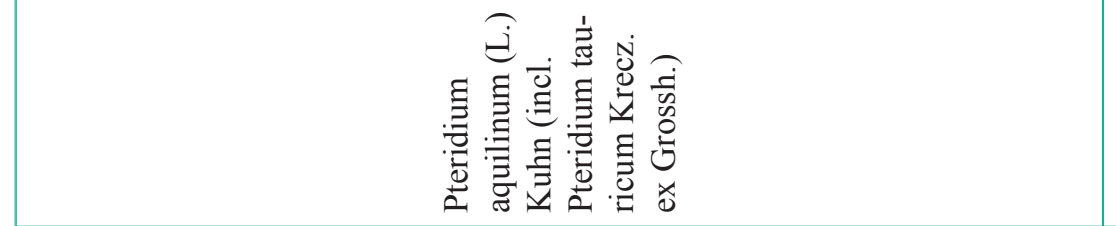 & 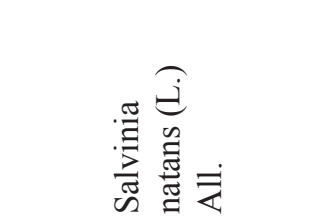 \\
\hline
\end{tabular}


Valentyna Minarchenko, Iryna Tymchenko, Tetyana Dvirna et al.

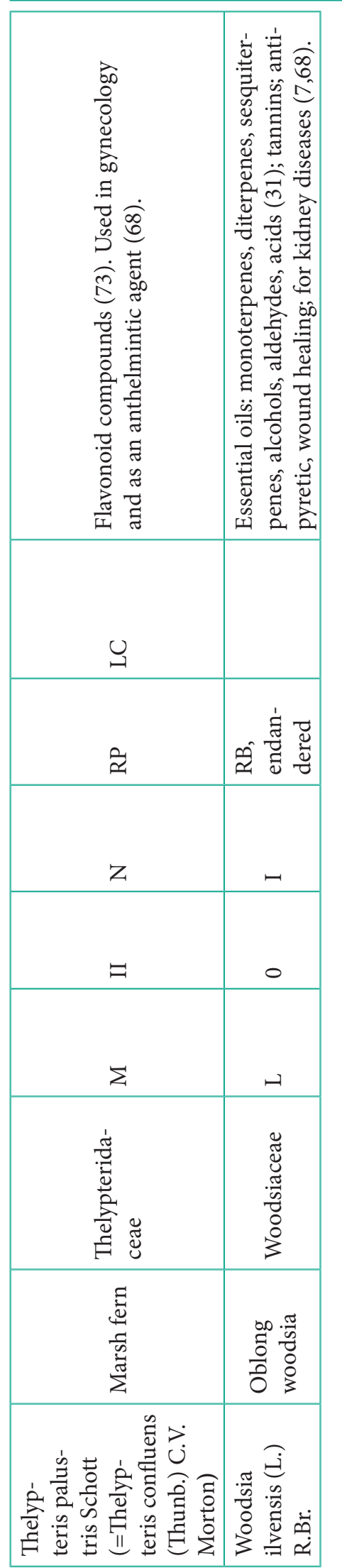

is part of a complex study of the medicinal plants of Ukraine with a goal to provide necessary information about the diversity, raw resources and necessity of protection of medicinal plants in the state.

\section{MATERIALS AND METHODS}

Regular field studies (expeditions) were carried out in different regions of Ukraine during the years 2002-2016. In the field, we have made geobotanical descriptions of localities, studied medicinal species and performed analysis of their involvement in plant communities. Additional information about the diversity, distribution, protection status, medicinal properties and use of ferns was received as a result of analyzing herbarium materials from various institutions of Ukraine, population survey during trips and literature data.

\section{RESULTS AND DISCUSSION}

Ferns do not hold significant economic importance in Ukraine. They are mostly used for decorative purposes in landscape gardening and occasionally in folk medicine for health benefits. Some of them (Pteridium aquilinum (L.) Kuhn, Onoclea struthiopteris (L.) Hoffm. and Matteuccia struthiopteris (L.) Tod.) are occasionally used for cooking purposes. It is a good source of protein and trace elements.

The results of the survey are presented in Table 1 , in which the plants are arranged in alphabetical order. For each species the following data is present: : Latin and English name of the fern species, name of the family, and family distribution and resource significance in Ukraine, population structure, protection status in Ukraine and Europe, and medicinal value.

The presented species of ferns belong to 16 families, with the obvious predominance of the Aspleniaceae (23\%) and Dryopteridaceae (23\%) families. Other families are few in numbers and mostly represented by small quantity of species.

A distribution analysis shows widespread species, which grow on most of the territory of Ukraine (41.02\%). The rest of the ferns have a limited distribution in some regions (30.77\%) (Polissya, Carpathian Mountains, forest-steppe zone, etc.) or are only known to be in certain locations (28.21\%). The last of these are rare ones and included to Red Book of Ukraine (12). Their populations are small with few 
representatives. Most of the fern species of Ukraine being shade and moisture-loving, grow under forest canopy or in specific habitats, mainly in the Polissya region. These forests are being heavily transformed by logging. Any disturbance of forest vegetation leads to ecological imbalance and destruction of most of the fern populations. With the increase of environment transformation the natural habitats of ferns are becoming small and fragmented, so some species are on the brink of extinction and protected at regional or national levels (see Table 1).

Based on the results of the evaluation of the resource potential of the analyzed ferns, they were divided into several groups of species (see Table 1). Based on estimation, only Athyrium filix-femina (L.) Roth, Dryopteris filix-mas (L.) Schott and Pteridium aquilinum have resource significance and are available for sustainable wild collection and wide economic importance. The resources of other species are limited and inaccessible for harvesting from the wild. Most of them are protected on regional, national or global level.

Thus, more than half of the medicinal ferns have little distribution in Ukraine and many of them are endangered and are in need of protection. Their populations, mostly, are small-numbered or represented by isolated individuals. For this reason, 11 species of medicinal ferns from the total number studied are protected at the state (national) level and are included in the Red Book of Ukraine (12); 19 species are protected at regional level and listed on the Regional Rare Checklists. Some of them are protected only in certain areas (administrative regions), where there is a threat of depletion of their populations. Besides that, ten species from the total number studied are threatened at a European level (see Table 1), according to data from global or European regional assessment (13).

The protection rank at European level of Botrychium matricariifolium (A. Braun ex Döll) W.D.J.Koch, Marsilea quadrifolia L. and Pilularia globulifera L. has been identified as Near Threatened. There are rare species with a scattered distribution throughout Europe. They are listed as threatened on all available national red lists, including Ukraine's, and populations are declining almost everywhere. Species, such as Adiantum capillus-ven- eris L., Botrychium lunaria (L.) Sw., Salvinia natans (L.) All., Onoclea struthiopteris, Polypodium vulgare L. and Thelypteris palustris (Salib.) Schott are classified in the European Red List as Least Concern as they are widespread and abundant, however they appear to be declining throughout much of their range with some localities going extinct (13). The first three species are added to the Red Book of Ukraine, however, the populations of Salvinia natans have been found lately in many localities with a high number of representatives and the overall trend is stable with range extensions around some river basins. Onoclea struthiopteris, Polypodium vulgare and Thelypteris palustris are abundant in large areas, although protected in some regions. Botrychium multifidum (S.G. Gmel.) Rupr. has been identified as Data Deficient (DD) on European level, but is in decline in Ukraine and included in the Red Book as rare species (Table 1). In addition, the Red Book of Ukraine includes Asplenium adiantum-nigrum L., Cheilanthes acrostica (Balb.) Tod., Cystopteris fragilis (L.) Bernh. and Woodsia ilvensis (L.) R.Br., as populations with a decreasing number of representatives.

The current main threat for many wild ferns of Ukraine is disturbance of the ecological balance of their living environment, including: general ecosystem dehumidification, wetland amelioration, forest exploitation (deforestation, intensive logging, decrease of the area of old-growth forests), habitat fragmentation as a result of anthropogenic transformation of the environment, wild fern collection, livestock grazing and related agricultural threats, local fires, recreation and tourism. The most sensitive ones to these threats are stenotopic species, the populations of which are characterized by weak adaptive properties, high sensitivity to any change in the habitat or the surrounding areas, slow regeneration after stress and implementation of life strategy in a stable environment (14).

There is a general trend in many parts of Ukraine towards a decrease in the humidity of ecosystems due to prolonged drought, draining of marshes and other wetlands, amelioration of wetlands and their subsequent use for agricultural purposes. As a result, we observe irreversible damage to the ecological balance of ecosystems and depletion in the populations of many medicinal ferns, such as Adiantum capillus-veneris, Marsilea quadrifolia, Pil-

Scripta Scientifica Pharmaceutica, vol. 4, No. 1, 2017, pp. 7-23 Medical University of Varna 
Valentyna Minarchenko, Iryna Tymchenko, Tetyana Dvirna et al.

ularia globulifera, Thelypteris palustris and others (Table 1). Further dehumidification of ecosystems threatens their survival. The majority of fern habitats are a fragmented and isolated as a consequence of human activity such as livestock grazing and pastures burning, recreation and tourism because plants cannot cope with the trampling, grazing and waste from stock.

Cutting of forest and unfavorable forest management are further dangers for most of the ferns growing under the canopy of trees, such as Asplenium adiantum-nigrum, A. scolopendrium L., Blechnum spicant (L.) Roth, Gymnocarpium dryopteris (L.) Newman, Onoclea struthiopteris, Oreopteris limbosperma (Bellardi \& All.) Holub, Ophioglossum vulgatum $\mathrm{L}$. The restoration of populations of these species may last a very long time. There is no information available on current population trends for these species, but the populations are likely to be declining and fragmented following the general trend of destruction and degradation of shallow wetland and forest habitats. In addition to the loss of habitats, overcollection of plants is a significant threat to some rare wild ferns. Many ferns of Ukraine are non-harvest plants, but some of them are used for landscape gardening that may be indicated as a potential risk of extinction.

The state of the majority of the studied medicinal ferns populations is threatened, as they have limited distribution and populations often are represented by isolated individuals and the resources are meager (see Table 1). Thus, harvesting of raw material from the natural environment poses a real threat of extinction.

Analysis of the data on the medicinal effect of biologically active compounds identified in the analyzed ferns showed a wide range of their properties. More than $80 \%$ of the ferns have anti-inflammatory, laxative, lactogenic, anthelmintic, diuretic, expectorant, anesthetic, antioxidant and hepatoprotective properties (Table 1). Most of the analyzed ferns (64.1\%) have been studied and found to be useful with their anti-inflammatory effect on the stomach and intestines, and their anthelmintic, astringent or light laxative effects. The most famous among them are Onoclea struthiopteris, Polypodium vulgare, Pteridium aquilinum and some others.
Concerning diseases of the respiratory system (including using them as an expectorant and antipyretic agent), it is known that nearly $45 \%$ of the analyzed fern species are used, indicating a vastly researched knowledge about medicinal ferns, which are used to treat respiratory problems. The information about the pharmacological properties or medicinal use of six species (Asplenium fontanum (L.) Bernh., Azolla mexicana C. Presl, Cheilanthes acrostica (Balb.) Tod., Dryopteris caucasica (A. Braun) Fraser-Jenk.\& Corley, Dryopteris villarii (Bellardi) Woyn.ex Schinz \& Thell., Oreopteris limbosperma (Bellardi \& All.) Holun and Pilularia globulifera L.) is insignificant to indeterminate, however, the main biologically active ingredients were investigated.

The results of the present study demonstrate that these ferns are not as important medicinally as vascular plants in Ukraine, but have considerable importance as obligate components in most of forest systems. Many of them need protection due to irreversible changes in their habitat. The featured table shows the common characteristics of wild medicinal ferns of Ukraine.

\section{CONCLUSION}

The use of ferns in Ukraine for their medicinal and other economic value, including ornamental use, is limited, but at the same time, the population densities of many species have decreased primarily due to deforestation and disturbance of habitats. Further research is needed to gather information about the population size, threats and trend of these species throughout their range. Therefore, a significant effort should be taken for the conservation of the species, which are highly sensitive to any change in the habitat. If the protection measures are followed strictly, further studies on ferns as perspective potential for pharmaceuticals could bring many more medicinal benefits.

\section{REFERENCES}

1. Lee CH, Shin SL. Functional Activities of Ferns for Human Health. In: Fernández H, Kumar A, Revilla A, editors. Working with Ferns: Issues and Applications. New York: Springer; 2010. p. 347-59.

2. Manickam VS, Benniamin A. Medicinal Pteridophytes of the Western Ghats, India. Indian J Tradit Know. 2007; 6(4): 611-18. 
3. Sarker SK, Hossain ABME. Pteridophytes of greater Mymensingh district of Bangladesh used as vegetables and medicines. Bangladesh J Plant Taxon. 2009; 16(1): 47-56.

4. Mir SA, Mishra AK, Reshi ZA, Sharma MP. Preliminary phytochemical screening of some Pteridophyte from district Shopian (J \& K). Int J Pharm Pharm Sci. 2013; 5(4): 632-7.

5. Valizadeh H, Ali S, Kordi FM, Dehghan H Bahadori MB. Cytotoxicity, Antioxidant Activity and Phenolic Content of Eight Fern Species from North of Iran. Pharm Sci. 2015; 21: 18-24.

6. Vasudeva SM. Economic importance of Pteridophytes. Indian Fern Journal. 1999; 16(1-2): 130-152.

7. Plant resources of Russia and neighboring countries: Part I. Families Lycopodiaceae - Ephedraceae; Part II. Additions to the 1-7th volumes. Budantsev AL editor. SPb: Peace and Family-95; 1996 (In Russian).

8. Minarchenko VM. Medical vascular plants of Ukraine (medical and resource value). Kyiv: Fitosociocentre; 2005 (In Ukrainian).

9. Han X, Li Z, Li CY, Jiaa WN, Wang HT, Wang $\mathrm{CH}$. Phytochemical constituents and biological activities of plants from the genus Dryopteris. Chem Biodivers. 2015; 12(8): 1131-62. doi: 10.1002/ cbdv.201400157

10. De Medeiros JM, Macedo M, Contancia JP, Nguyen C, Cunningham G, Miles DH. Antithrombin activity of medicinal plants of the Azores. J Ethnopharmac. 2000; 72 (1-2): 157-65. doi: 10.1016/ S0378-8741(00)00226-9

11. Vasheka OV, Bezsmertna OO. Ferns atlas of Ukrainian flora: monograf. Kyiv: Palyvoda A.V.; 2012 (In Ukrainian).

12. Didukh Ya P (ed). Red Book of Ukraine. Kyiv: Globalkonsaltyng, 2009.

13. The IUCN Red List of Threatened Species [Internet]. Version 2016-3. [Downloaded on 2017 January 24; cited 2017 March 02]. Inc. Available from: http://www.iucnredlist.org

14. Minarchenko V. Medicinal plants of Ukraine: diversity, resources, legislation. Medicinal Plant Conservation Newsletter. 2011; 14: 7-13. http://cmsdata. iucn.org/downloads/mpc_14_1.pdf

15. Al-Snafi AE. The chemical constituents and pharmacological effects of Adiantum capillus-vener- is - a review. Asian J Pharm Sci Tech. 2015; 5(2): $106-11$.

16. Singh M, Singh N, Khare PB, Rawat AKS. Antimicrobial activity of some important Adiantum species used traditionally in indigenous systems of medicine. J Ethnopharmac. 2008; 115(2): 327-9. doi: 10.1016/j.jep.2007.09.018

17. Ishaq MS, Hussain MM, Siddique M, Ali G, Khattak M, Ahmad S, et al. In Vitro Phytochemical, Antibacterial, and Antifungal Activities of Leaf, Stem, and Root Extracts of Adiantum capillus veneris. Scientific World J. 2014. doi. org/10.1155/2014/269793.

18. Sen A, Gosh PD. A note on the ethnobotanical studies of some pteridophytes in Assam. Indian J Tradit Knowl. 2011; 10(2): 292-5.

19. Ibraheim ZZ, Ahmed AS, Gouda YG. Phytochemical and biological studies of Adiantum capillusveneris L. Saudi Pharm J. 2011; 19(2): 65-74. doi: 10.1016/j.jsps.2011.01.007

20. Mannan MM, Maridass M, Victor B. A Review on the Potential Uses of Ferns. Ethnobotanical Leaflets. 2008; 12: 281-5.

21. Dar A, Faizi S, Naqvi S, Roome T, Zikr-ur-Rehman S, Ali M, et al. Analgesic and antioxidant activity of mangiferin and its derivatives: the structure activity relationship. Biol Pharm Bull. 2005; 28(4): 596-600.

22. Dall'Acqua $\mathrm{S}$, Tomè $\mathrm{F}$, Vitalini $\mathrm{S}$, Agradi E, Innocenti G. In vitro estrogenic activity of Asplenium trichomanes L. extracts and isolated compounds. J Ethnopharmacol. 2009; 122(3): 424-9. doi: 10.1016/j.jep.2009.02.012

23. Imperato F. A new sulfated flavonol glycoside in the fern Asplenium fontanum. Bernh Chem Ind. $1980 ; 540-1$.

24. Imperato F. Xanthone 2,4-di-C-glycosides from Asplenium adiantum-nigrum. Phytochemistry. 1991; 30: 3839-40. doi: 10.1016/0031-9422(91)80132-K

25. Iwashina T, López-Sáez JA, Herrero A, Kitajima J, Matsumoto S. Flavone glycosides from Asplenium foreziense and its five related taxa and A. incisum. Biochem Systematics and Ecology. 2000; 28(7): 665-71.

26. Fan $\mathrm{P}$, Zhao L, Hostettmann K, Lou H. Chemical constituents of Asplenium ruta-muraria L. Nat Prod Res. 2012; 26(15): 1413-8. doi: 10.1080/14786419.2011.599805 
Valentyna Minarchenko, Iryna Tymchenko, Tetyana Dvirna et al.

27. Iwashina T, Matsumoto S. Flavonoid Properties of six Asplenium species in Vanuatu and New Caledonia, and Distribution of Flavonoid and Related Compounds in Asplenium. Bull Natl Mus Nat Sci. 2011; Ser. B, 37(3): 133-45.

28. Ashalatha K. Isolation \& characterization of biologically active compounds from the medicinal plants Salvinia natans and Decalepis hamiltonii and total synthesis of cleistenolide and yashabushidiol derivatives. 2011 [updated 2013 Apr. 22; cited 2017 Jan 20]. Available from: http://hdl.handle. net/10603/8226

29. Mizuno M, Kyotani Y, Iinuma M, Tanaka T, Kojima H. Iwatsuki K. Kaempferol glycosides in Asplenium scolopendrium Newm. Zeitschrift für Naturforschung C. 1990; 45(3-4): 143-6. doi: 10.1515/ znc-1990-3-401

30. You-Min S, Young-Won C, Min-Hye Y, Jin-Woong K. Terpenoid constituents from the aerial parts of Asplenium scolopendrium. Nat Prod Sci. 2008; 14(4): 265-8.

31. Aibuldinov Ye, Ozek G, Rakhmadiyeva S, Basher KHC. Gas-chromatographic and mass spectrometric evaluation of essential oils of four ferns from Kazakhstan. Newsletter of L.N.Gumilyov Eurasian National University. 2012; 6: 265-70.

32. Imperato F. Flavonol glycosides from ferns of the genera Asplenium and Cheilanthes. Biochem Syst Ecol. 1989; 17(2): 161-6. doi: 10.1016/0305-1978(89)90074-4

33. Froissard D, Fons F, Bessière JM, Buatois B, Rapior S. Volatiles of French ferns and «fougère» scent in perfumery. Nat Prod Commun. 2011; 6(11): 1723-6.

34. Singh S, Singh R. Ethnomedicinal use of Pteridophytes in reproductive health of tribal women of Pachmarhi biosphere reserve, Madhya Pradesh, India. Int J Pharm Sci Res. 2012; 3(12): 4780-90.

35. Iwashina T, Matsumoto S. Flavonoid variation and evolution in Asplenium normale and related species (Aspleniaceae). Journal of Plant Research. 1994; 107(3): 275-82.

36. Akmuradov A, Rakhmanov O. Medicinal resources of pteridoflora of Turkmenistan, applied to folk medicine. Healthcare of Turkmenistan. 2011; 1: 29-34.

37. Akmuradov A, Shaiymov BK. Medical plants of the Koitendag flora used in folk medicine. Sib Med J. 2015; 4: 86-9.
38. Bahadori MB, Kordi FM, Ahmadi AA., Bahadori Sh, Valizadeh H. Antibacterial evaluation and preliminary phytochemical screening of selected ferns from Iran. Res J Pharmacognosy (RJP). 2015; 2(2): $53-9$.

39. Kumar A, Kumari J, Kumar H, Nath A, Singh JK., Ali M, et al. Hepatoprotective and antioxidant effect of Azolla filiculoides on profenofos induced hepatotoxicity in swiss albino mice. Carib J Sci Tech. 2014; 2: 372-7.

40. Pieterse AH, de Lange L, Van Vliet JP. A comparative study of Azolla in the Netherlands. Acta Botanica Neerlandica. 1977; 26(6): 433-49.

41. Pereira AL, Carrapiço F. Histochemistry of simple hairs from the foliar cavities of Azolla filiculoides. Plant Biosystems. 2007; 141(3): 323-8. doi: 10.1080/11263500701627588

42. Masood A, Zeeshan M, Abraham G. Response of growth and antioxidant enzymes in Azolla plants (Azolla pinnata and Azolla filiculoides) exposed to UV-B. Acta Biol Hung. 2008; 59 (2):247-258. doi: 10.1556/ABiol.59.2008.2.10

43. Holst RW. Anthocyanins of Azolla. American Fern Journal. 1977; 67: 99-100.

44. Plants for a future [Internet]. [updated 2014 Oct 27; cited 2017 May 02]. Available from: http://www. pfaf.org/user/Default.aspx

45. Srivastava K. Ethnobotanical Studies of Some Important Ferns. Ethnobotanical Leaflets. 2007; 11: 164-72.

46. Đurdevih L, Mitrović M, Pavlović P, Bojović S, Jarić S, Oberan L, et al. Total phenolics and phenolic acids content in leaves, rhizomes and rhizosphere soil under Ceterach officinarum D.C., Asplenium trichomanes L. and Adiantum nigrum L. in the gorge of Sićevo (Serbia). Ekológia (Bratislava). $2007 ; 26(2)$ : 164-73.

47. Guarino C, De Simone L, Santoro S. Ethnobotanical Study of the Sannio Area, Campania, Southern Italy. Ethnobotany Research \& Applications. 2008; 6: 255-317.

48. Ullah F, Ullah A, Sohail A, Khan R. Diversity, distribution and ecological importance of weeds in the maize crop at maidan valley, dir (l), khyber pakhtunkhwa, Pakistan. Pak J Weed Sci Res. 2015; 21(4): 543-53.

49. Vogler G, Donath O, Saukel J, Rauch AW, Kählig H, Krenn L. Polar phenolic compounds in Dryopter- 
is filix-mas and Dryopteris dilatata. Verh Zool-Bot Ges Österreich. 2012; 148/149: 279-89.

50. Imperato F. Kaempferol 3-O-(acetylrutinoside), a new flavonoid and two Nnew fern constituents, quercetin 3-O-(acetylglucoside) and 3-O(acetylrutinoside) from Dryopteris villarii. American Fern Journal. 2006; 96(3): 93-6. doi: 10.1640/0002-8444(2006)96[93:SN]2.0.CO;2

51. Kovganko NV, Kashkan ZhN, Krivenok SN, Potapovich MV, Eremin AN, Metelitsa DI. Bioactive compounds in the flora of Belarus. 2. Astragalin, an effective protector of catalase from ultrasonic inactivation in aqueous solutions. Chemistry of Natural Compounds. 2004; 40(1): 71-4. doi:10.1023/B:CONC.0000025471.16712.bf

52. Uma R, Pravin B. In vitro Cytotoxic Activity of Marsilea quadrifolia Linn of MCF-7 Cells of Human Breast Cancer. Int Res J Medical Sci I. 2013; 1(1): 10-3.

53. Ripa FA, Nahar L, Haque M, Islam MM. Antibacterial, Cytotoxic and Antioxidant Activity of Crude Extract of Marsilea quadrifolia. Eur J Sci Res. 2009; 33(1): 123-9.

54. Li S, Zhang D, Yang L, Li Y, Zhu X, Kmonílková E, et al. HPLC Quantitative Analysis of Main Stilbenes and Flavones in Different Parts of Matteuccia struthiopteris. Journal of Chemistry. 2013; 2013. doi.org/10.1155/2013/452610

55. Li B, Ni Y, Zhu LJ, Wu FB, Yan F, Zhang X, et al. Flavonoids from Matteuccia struthiopteris and their Anti-influenza virus (H1N1) activity. J Nat Prod. 2015; 78(5): 987-95.

56. Zhang D, Yang L, Fu MH, Tu YY. Studies on chemical constituents of rhizome of Matteuccia struthiopteris III. China Journal of Chinese Materia Medica. 2008; 33(14): 1703-5.

57. Yang L, Wang MY, Zhao YY, Tu YY. Chemical constituents of the rhizome of Matteuccia struthiopteris. Acta Pharmaceutica Sinica. 2005; 40(3): 252-4.

58. Yang L, Wang MY, Zhao YY, Tu YY. Studies on chemical constituents in rhizome of Matteuccia struthiopteris. China Journal of Chinese Materia Medica. 2004; 29(7): 648- 9.

59. Yang L, Zhao YY, Tu YY Chemical constituents of the rhizome of Matteuccia struthiopteris. China Journal of Chinese Materia Medica. 2003; 28: 278-9.

60. Borozenets AS, Andrianova GS. The search for carriers of vitamins $\mathrm{P}$ and $\mathrm{C}$ among wild flora of the
Far East. Proceedings of the Khabarovsk Medical Institute. 1962; 23(1): 147-50 (In Russian).

61. Shreter AI Medicinal flora of the Soviet Far East. Moscow: Medicine; 1975 (In Russian).

62. Clericuzio M, Burlando B, Gandini G, Tinello S, Ranzato E, Martinotti S, et al. Keratinocyte wound healing activity of galactoglycerolipids from the fern Ophioglossum vulgatum L. J Nat Med. 2014; 68(1): 31-7. doi: 10.1007/s11418-013-0759-y

63. Clericuzio M, Tinello S, Burlando B, Ranzato E, Martinotti S, Cornara L, et al. Flavonoid oligoglycosides from Ophioglossum vulgatum L. having wound healing properties. Planta Med. 2012; 78(15): 1639-44. doi: 10.1055/s-0032-1315149

64. Fons F, Froissard D, Bessière JM, Buatois B, Rapior S. Biodiversity of Volatile Organic Compounds from Five French Ferns. Nat Prod Commun. 2010; 5(10): 1655-8.

65. Imperato F. A new flavonoid, quercetin 3-O-(X"-acetyl-X"-cinnamoyl-glucoside) and a new fern constituent, quercetin 3-O(glucosylrhamnoside) from Dryopteris villarii. American Fern Journal. 2007; 97(2): 233-6. doi: 10.1640/0002-8444(2007)97[124:SN]2.0.CO;2

66. Assessment report on Polypodium vulgare L., rhizoma. European Medicines Agency Evaluation of Medicines for Human Use. Doc. Ref.: EMEA/ HMPC/600669/2007 [Internet]. 2008. [updated 2008 Nov 6; cited 2017 May 25]. Available from:. http://www.ema.europa.eu/docs/en_GB/document_library/Herbal_-_HMPC_assessment_report/2009/12/WC500018581.pdf

67. Soare LC, Ferdeş M, Deliu I, Gibea A. Studies regarding the antibacterial activity of some extracts of native pteridophytes. UPB Sci Bull. 2012; Series B, 74(1): 21-6.

68. Shishmarev VM. Medical ferns of Burytia. Buryat State University Bulletin. 2013; 12: 69-71 (In Russian).

69. Chen N. Study on the extraction of flavonoid compound in Pteridium aquilinum (L.) and its antioxidant property. Food and Ferment Indust. 2003; 29(11): 63-6.

70. Xu W, Zhang F, Luo Y, Ma L, Kou X, Huang K. Antioxidant activity of a water-soluble polysaccharide purified from Pteridium aquilinum. Carbohydr Res. 2009; 344(2): 217-22. doi: 10.1016/j. carres.2008.10.021 
71. Srilaxmi P, Sareddy GR, Kavikishor PB, Setty OH, Babu PP. Protective efficacy of natansnin, a dibenzoyl glycoside from Salvinia natans against $\mathrm{CCl}_{4}$ induced oxidative stress and cellular degeneration in rat liver. BMC Pharmacology. 2010; 10:13. doi: 10.1186/1471-2210-10-13

72. Yang X et al. Encyclopedic reference of traditional Chinese medicine. Berlin Heidenberg: SpringerVerlag;. 2003.

73. Murakami T, Wada H, Tanaka N, Chen CM. Chemical and Chemotaxonomical Studies of Filices. LXV.: A Few New Flavonoid Glycosides. (2) (Organic). Journal of the Pharmaceutical Society of Japan. 1986; 106(11): 982-8. 